\title{
Unravelling Relations Between Immigration, Crime and Superdiversity in the United States of America, Europe, Australia and New Zealand
}

\author{
Carl Hermann Dino Steinmetz \\ Expats \& Immigrants Besloten Vennootschap, Amsterdam, The Netherlands
}

\section{Email address:}

carl@expats-immigrants.com

\section{To cite this article:}

Carl Hermann Dino Steinmetz. Unravelling Relations Between Immigration, Crime and Superdiversity in the United States of America, Europe, Australia and New Zealand. Humanities and Social Sciences. Vol. 8, No. 1, 2020, pp. 7-19. doi: 10.11648/j.hss.20200801.12

Received: December 19, 2019; Accepted: January 6, 2020; Published: February 4, 2020

\begin{abstract}
A substantial number of western cities and its neighbourhoods, in Europe, the United States of America, Australia and New Zealand became super diverse, majority-minority cities and in most of these cities the "true" citizen is an immigrant (old- and newcomer) who lives in these cities for four generations. This change in western cities with a long mostly unknown tradition of immigration [1, 2] to majority-minority cities may have an impact on the development of crime. Scheffer claimed that newcomers unfamiliar with the habits, norms and values of their new fatherland first do become victims of crime, and then become more susceptible to witness perpetrators committing crime [3]. Both victimization and witness experiences can lower the threshold for committing a crime. This cycle is documented for bicycle theft [4]. The assumption is that immigrants, refugees and expats are vulnerable as newcomers in western countries. On top of these newcomers' experiences with crime, the first up to fourth generation is excluded, discriminated and polarized in education, healthcare, workplace and neighbourhoods [5]. Possible causes are clashes between individualism and collectivism, racism and exclusion, a difference between mother and fatherland cultures concerning requirements, norms and values, polarization between WE (Our Kind of People) and THEM (Other Kind of People) and for African immigrants and refugees a community law system versus a criminal justice system [6]. The consequences of the above-mentioned system errors for the way in which immigrants, refugees and expats experience crime are documented in Dutch books and dissertations, like 'Moroccan in Europe, Criminal in the Netherlands' [7] more family violence [8] among Dutch-Moroccans then original Dutch and more short-term psychosis among people of colour [9]. This article suggests that victimology as a science has failed to reflect the contemporary transitions of cities and neighbourhoods where immigrants, refugees and expats together became a clear majority in super diverse cities and neighbourhoods [10]. Secondly this article presents international data about the suggestion that immigration causes more crime, with the champion of this message Donald Trump. In the United States of America and Europe there is no proof for an increase of crime as a consequence of newcomers. The opposite might even be true. Newcomers and immigrants however are more often victims of crime than original indigenous people $[11,12]$.
\end{abstract}

Keywords: Super Diverse Cities and Neighbourhoods, Crime, Immigrants, and Refugees

\section{Introduction}

This article first of all outlines indirectly the consequences of super diversity, in particular to the regular influx of small groups of immigrants, refugees and expats, on crime. Indirectly, there is no data available on the effect of a regular and continuous increase in immigrants, refugees and expats in metropoles, cities and neighbourhoods on the nature and extent of crime. This article secondly pays mainly attention to the cycle of victimization, becoming a bystander and sometimes an offender. Crime has its roots in learning processes that are part of human relationships.

Superdiversity might also take a prominent place in near future in the existing old and new metropoles, cities and neighbourhoods of these metropoles and cities along the New Silk Roads between China, Russia, Southeast- and Central Asia, Turkey, the Middle East, Europe and both America's [2]. 


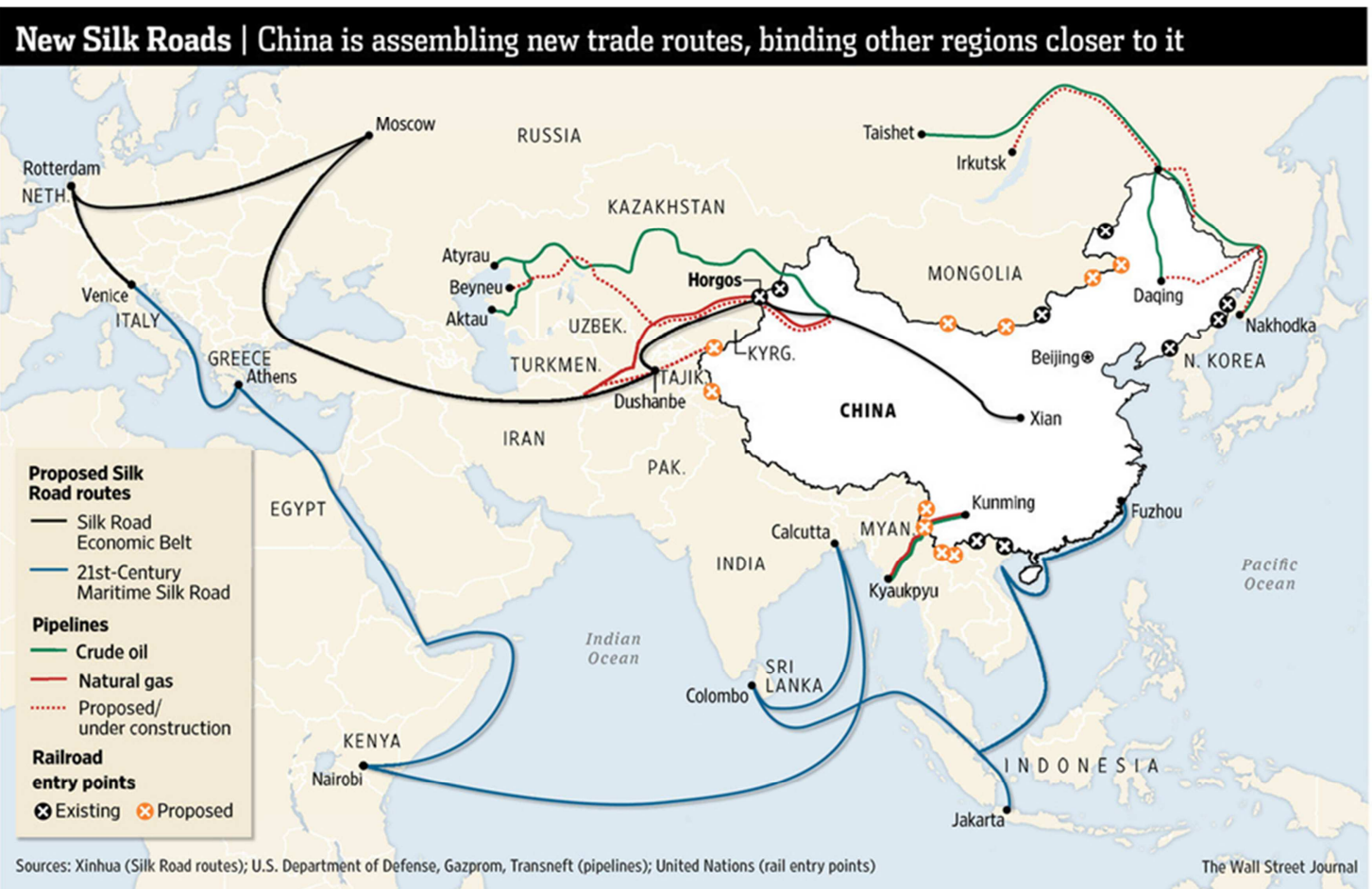

Figure 1. The new Silk Roads.

Because many crime data do not make a structural distinction between indigenous and originally nonindigenous residents of a country, metropolis / city and neighbourhood as perpetrator, victim and / or witness, visualizing crime trends is provisional.

Several hypotheses have been formulated for the relation between crime, superdiversity and immigration. Donald Trump for instance tweets, that immigrants from SouthAmerica are criminals. Literally Trump said: "when Mexico is sending its people, they are not sending the best. They are sending people that have lots of problems, and they are bringing those problems with us. They are bringing drugs, they are bringing crime, and they are rapists" [2, p. 47]. Trump's view evokes the suggestion that the relationship between crime and immigration is positive. Other hypotheses are that crime rates drop after immigration or remains at the same level. These hypotheses are further investigated in this article. This is done on the basis of a literature study on the United States, Europe, Australia and New Zealand, in particular on the basis of police data, victim surveys and data on detainees.

Bell [16] said, "There is no simple link between immigration and crime. Most studies find that larger immigrant concentrations in an area have no association with violent crime and, overall, fairly weak effects on property crime. However, immigrant groups that face poor labour market opportunities are more likely to commit property crime. But this is also true of disadvantaged native groups. The policy focus should therefore be on the crime-reducing benefits of improving the functioning of labour markets and workers' skills, rather than on crime and immigration per se. There is also a case for ensuring that immigrants can legally obtain work in the receiving country, since the evidence shows that such legalization programs tend to reduce criminal activity among the targeted group. the evidence, based on empirical studies of many countries, indicates that there is no simple link between immigration and crime, but legalizing the status of immigrants has beneficial effects on crime rates."

Caution with available criminal justice data is required. Accumulated research indicates that police and criminal records (suspect rates, crime rates, conviction rates and prison populations) are biased against immigrants (including short-term and undocumented immigrants) and refugees:

i. "Immigrants and their native-born children are generally found to be overrepresented among crime suspects and convicted offenders in Europe. We reasoned that official crime figures are likely to be biased against newcomers and their children, and that such biases may explain part of the transatlantic differences in the relationship between immigration and crime, as indicated by official data [13, pp. $1 \& 17]$."

ii. "Immigrants from certain parts of the world are more likely to be incarcerated than others. Of all legal immigrants, those from Latin America, Other Asia (not Indian and East-Asia), and Africa have the three highest incarceration rates. For illegal immigrants, those from Latin America have the highest incarceration rate of any group - in part because they are more likely to be incarcerated for immigration offenses and in ICE detention facilities than immigrants from any other region-followed by those from Africa [14, p. 4]." "The younger the immigrants are upon arrival in the United States and the longer they are here, the more 
likely they are to be incarcerated as adults. Possible discrimination by the judicial system may result in higher number of convictions [14, p. 7]."

iii.Suspects and immigrants. "The prejudice that many native Dutch citizens have against immigrants could cause the police to more closely monitor ethnic groups, especially Moroccans. The most common stereotype attributed to Moroccans by native Dutch citizens is that they are violent and engage in crime: in other words, they are the criminal other. Consequently, research is needed to assess whether native Dutch citizens are more likely to perceive behaviour as 'suspicious' if they associate the behaviour with Moroccans rather than native Dutch citizens. Additionally, scholars need to investigate whether the native Dutch are more likely to report what they perceive to be 'suspicious' behaviour to the police if they attribute the behaviour to immigrants rather than to native Dutch citizens $[15, \mathrm{p}$. 15]."

\section{Population Changes European Countries, Metropolises, Large Cities and Its Neighbourhoods}

$23 \%$ of the Dutch population in the Netherlands was in 2018 of non-Dutch origin [17]. The largest cities in the Netherlands are super diverse. Superdiversity is a concept invented in 2007 by Steven Vertovic that describes the changing immigration patterns and their impact on (British) society. Vertovic defines superdiversity as follow [18, p. 3]: "Superdiversity points out that the new immigration patterns not only entail variable combinations and dynamic interactions of the following traits, such as differential legal statuses and their concomitant conditions, divergent labour market experiences, discrete configurations of gender and age, patterns of spatial distribution, and mixed local area responses by service providers and residents, but that their combinations produced new hierarchical social positions, statuses or stratifications. These, in turn, entail: new patterns of inequality and prejudice including emergent forms of racism, new patterns of segregation, new experiences of space and "contact", new forms of cosmopolitanism and creolization (including what's more recently discussed in terms of conviviality and multiculture), and more."

Since 2007 superdiversity is being used more and more, Crul developed this concept for the European mainland [10]. With this new paradigm, the focus is on two crucial changes. The starting point is a quantitative transition, with the sharp increase in the number of people with an immigrant background in recent decades. A qualitative transition also plays a role: superdiversity of the 21 st century differs from the immigration of the 20th century through a fundamental change in immigration patterns and its impact on society. Diversification of diversity is the new reality.

"One of the great benefits of a superdiversity lens is that it has the virtue of bringing new perspectives to familiar issues and advancing our understanding of social processes by reconstituting our perceptual field and identifying connections not previously seen or emphasized. However, the superdiversity lens often overlooks power differentials at a level beyond the neighbourhood. Or to phrase it somewhat differently, the superdiversity lens has so far been less able to capture the vertical phenomena that reflect the social, economic, and political power of the native majority. This may be partly because this would require a lens operating on a macro scale, rather than a micro one [19, pp. 3 and 12]."

Table 1. Countries and cities, total population, year and percentage of immigrants.

\begin{tabular}{|c|c|c|c|}
\hline Country/city & Total population & Year & $\%$ immigrants \\
\hline EU-28 & 512.400 .000 & 2018 & 12 \\
\hline Netherlands & 17.412 .00 & 12 December 2019 & 23 \\
\hline Amsterdam & 862.965 & 2019 & 54,4 \\
\hline The Haque & 537.833 & 2019 & 54,7 \\
\hline Rotterdam & 644.618 & 2019 & 51 \\
\hline Utrecht & 352.866 & 2019 & 35 \\
\hline Belgium & 11.561 .953 & 2019 & 25 \\
\hline Antwerp & 526.000 & 2019 & 39 \\
\hline Brussels & 2.065 .284 & 2019 & 70 \\
\hline Germany & 82.790 .000 & 2018 & 14,8 \\
\hline Berlin & 3.556 .792 & 2019 & 20 \\
\hline Munich & 1.542 .860 & 2017 & 28,3 \\
\hline United Kingdom & 66.440 .000 & 2018 & 14 \\
\hline London & 8.900 .000 & 2018 & $2011: 36,7$ \\
\hline Paris & 2.141 .000 & 2019 & 60 \\
\hline Spain & 46.660 .000 & 2018 & 12,8 \\
\hline Madrid & 6.550 .000 & 2018 & 16 \\
\hline Barcelona & 5.515 .000 & 2018 & 49 \\
\hline Italy & 60.480 .000 & 2018 & 10 \\
\hline Rome & 4.234 .000 & 2018 & 12,8 \\
\hline Milan & 3.132 .000 & 2018 & 14,5 \\
\hline
\end{tabular}


The average number of immigrants in the EU-28 is $12 \%$ (in 2018 the number of immigrants are 38.2 million non-EU citizens and 21.8 million inhabitants were born in a different EU member state [20, p. 11]. This percentage of immigrants is larger for large cities. In $201954,4 \%{ }^{1}$ of the Amsterdam population, the capital of the Netherlands with almost 860 thousand inhabitants in 2018, is originally from another country than the Netherlands. Under 15 years two thirds of children and youngsters in Amsterdam do have an origin other than Dutch. In Rotterdam and The Hague, just over half of the population comes from abroad. Furthermore, in the Randstad with around 8.2 million people in 2016, the number of residents original from other countries then the Netherlands is in between $40 \%$ and $47 \%^{2}$. In Utrecht, more than one third of the population is of foreign descent.

Are big cities in the Netherlands an exception with regard to a superdiverse composition of the population? What about other European cities? In Belgium the number of original foreign born Belgians is $25 \%^{3}$, mainly French, Italian and Dutch people and a smaller number non-western. In Antwerp $^{4}$, a city of half a million inhabitants in $2017,75 \%$ of residents between 0-9 years of age are of non-Belgian origin. In $202055 \%$ of the Antwerp inhabitants will be of nonBelgium origin (with a large population of Turks, Romanians and Bulgarians). In Brussels ${ }^{5}$, the EU capital city, with a population in 2016 of more than 2 million people, $30 \%$ was foreign born and 25\% Muslims. Eurostat estimated the foreign-born population in France to be 8.18 million $^{6}$ (12.2\% of the French population). 3.2\% was born in another EU country. In Paris, a city of 2, 2 million people and the Paris Region of 12.7 million in $2019^{7}$, the estimated number of people of non-French descent of the first generation is $20 \%$ for Paris and $40 \%$ of the children in Paris have at least one parent as a first-generation immigrant. In France, it is forbidden by law to ask in population screenings about religion and ethnicity. The aforementioned estimates of immigrants, refugees and expats are probably based on the place of birth, which is an indirect indication of the extended families origin of (grand) children of immigrants, refugees and former expats. In Barcelona, a city of around 1.7 million people in 2016, the number of immigrants in $2013^{8}$ is nearly $49 \%$. In Madrid, the capital of Spain with approximately 3.3 million $^{9}$ inhabitants, estimations in 2019 show that $16 \%$ van the total population is of foreign descent (mainly South-

\footnotetext{
1 http://www.republiekallochtonie.nl/blog/feiten/samenstelling-van-deamsterdamse-bevolking

$2 \mathrm{https} / /$ www.pbl.nl/sites/default/files/cms/afbeeldingen/015i rpg13.pdf)

$3 \mathrm{https} / /$ www.statista.com/statistics/517235/foreign-population-of-belgium-byorigin/; https://www.indexmundi.com/belgium/demographics profile.html

4 https://sceptr.net/2018/03/antwerpen-bijna-75-inwoners-0-9-jaar-allochtoneorigine/

$5 \mathrm{http}: / /$ worldpopulationreview.com/world-cities/brussels-population/ $6 \mathrm{https} / / /$ ec.europa.eu/eurostat/statistics-explained/images/c/c6/Foreignborn_population_by_country_of_birth\%2C_1_January_2018_.png

$7 \mathrm{http} / /$ worldpopulationreview.com/world-cities/paris-population/

$8 \mathrm{https}$ //homagetoben.com/barcelona-immigration-statistics/

9 http://worldpopulationreview.com/world-cities/madrid-population/
}

Americans, East-Europeans, and Moroccans etc.). "Immigrants are largely concentrated in specific districts of Madrid, including Usera (28.4\%), Centro (27\%), Carabanchel (23\%), and Tetuan 22\%)." In Rome, Italia's capital city of approximately 2.9 million ${ }^{10}$ inhabitants in 2016 and 4.3 percent in the metropolitan area, 9,5\% is non-Italian mainly East-European (Romanian, Ukrainian, Polish and Albanian). In Germany the number of foreign born Germans in 2018 (population in 2019 is 83.6 million) is $13.7 \%{ }^{11}$ of which $9.2 \%$ was born outside the EU. Specifically, Germany will have 20.8 million immigrants $(25 \%)$ in 2019 . Berlin, German's capital city had in 20163,5 million inhabitants ${ }^{12}$ and in "the Berlin-Brandenburg Metropolitan Region with a population of 5.8 million the populations comes from more than 180 countries." In 2016 Stockholm Sweden's capital city had a population of 935.000 and now 1,6 million, $27 \%$ of the Stockholm inhabitants were in 2016 of a non-Swedish origin. London, the capital city of the United Kingdom, is one of the most ethnically diverse cities in the world. A 2000 survey of school children in London reported that over 300 languages were spoken at home. "At the 2011 census ${ }^{13}$, London had a population of $8,173,941$. Of this number of people, $44.9 \%$ were white British, $37 \%$ of the population were born outside the UK, including $24.5 \%$ born outside Europe."

A preliminary conclusion based on the aforementioned data is that superdiversity is an existing phenomenon or a phenomenon that might soon arise in more western cities.

\subsection{The Social Consequences of Superdiversity}

The focus of the aforementioned data has been on ethnic differences in the superdiverse 'New World in Western metropoles, cities and neighbourhoods'. Other immigrant (old- and newcomers) characteristics of superdiverse metropoles, cities and neighbourhoods are socio-legal, political status, socio-cultural (like language and religion), economic status, and opportunities for earning a livelihood (taking into consideration socio-economic inequality), gender and the interaction between two or more of these characteristics [21]. Another characteristic of superdiverse metropoles, cities and neighbourhoods is the relation between immigration (new- and oldcomers) and crime, in particular for those cities with immigrants, refugees and expats who developed from a minority to joint majority.

Superdiversity is considered as a complex concept since immigration changed in the last two decades: not anymore large groups of immigrants are moving to a new fatherland but small pockets of immigrants from a multitude of countries. The concept superdiversity contains at least 10 dimensions. These dimensions are mobility diversity, legal status diversity, educational diversity, income diversity,

\footnotetext{
$10 \mathrm{http}: / /$ worldpopulationreview.com/world-cities/rome-population/

$11 \mathrm{https} / /$ ec.europa.eu/eurostat/statistics-explained/images/c/c6/Foreignborn_population_by_country_of_birth\%2C_1_January_2018_.png

$12 \mathrm{http} / /$ worldpopulationreview.com/world-cities/berlin-population/

$13 \mathrm{https}$ //en.wikipedia.org/wiki/Ethnic_groups_in_London
} 
generational diversity and ethnic diversity according to Steven Vertovic, Daniel Hiebert, Alan Gamlen, and Paul Spoonley in their presentation 'Superdiversity [22]. Their statement about Australia, Canada and New Zealand, in particular Sidney, Vancouver and Auckland and its neighbourhoods is that today's migration has made cities more diverse than ever-in multiple ways'. They differentiate between the national, metropolitan and neighbourhood level. They introduced in 2018 a multivariate geographical mapping tool containing many of the aforementioned characteristics of immigrants and original indigenous people but also motives to immigrate, like humanitarian, family, economic and other [22].

\subsection{Comments}

This article on the relationship between immigration, refugees and crime unfortunately only focuses on retaliatory justice and not on restorative justice, particularly unfortunate for immigrants, refugees and expats from non-Western countries and continents who are used to restorative justice. The Tutu's [23] said that the eye-for-an-eye treatment is the basis of restorative justice. In western counties, the responsibility for restorative justice has been transferred to state and justice system. When the law is broken, it is a crime against the State. Crime in Western countries is seen as an individual act with consequences for the individual criminal, victim and bystander. Restorative justice, however, uses as a starting point that crime is not an act against the state but against one or more human beings and against the community to which these humans belong. Accountability in this model is that the offender takes responsibility for the harm she, he or they caused and for taking actions to repair the hurt. Victims are not peripheral in the restorative justice system."

\section{Immigration and Crime in the United States of America}

When drawing conclusions our eyes should be wide open because of the danger associated with generalization. It is my firm conviction that customization is necessary. An educational example from the United States of America is: "athletic extracurricular activity involvement is an insulating factor for White Americans but a potential risk factor for Latino Americans and Asian Americans. After all, youth who misbehave have an increased exposure to violence and victimization [24]."

"It is since colonial days in the United States of America a common believe that immigrants are members of a criminal class who threaten community cohesion by committing a disproportionately large number of violent and property crimes. Violent crimes include homicide, rape, robbery, and assault. Property crimes include theft and fraud. Some offenses are crimes of habitation that involve threats against a person and their property (for example, burglary). American citizens believe that immigrants are a threat to their safety and engage in many violent and property crimes $[11, \mathrm{pp} .1$ 2]." According to Bernat $[11$, p. 2] immigrants in the US used to be Europeans (60\% in 1960 to $11 \%$ in 2015 ) and new immigrants (newcomers) in the US are coming from Asia, South-America, Afrika and the Middle-East $(35 \%$ of the foreign born). The Migration Policy Institute (2015) estimates that "Immigrants and their U.S.-born children now number approximately 80 million persons, or one-quarter of the total U.S. population $[11$, p. 2)."

Immigrants are more likely to be victims of crime (violence, hate crime, state-crime and property crime) [25, 26, 8]. Crime victims born abroad may not report their victimization because they fear that they will experience negative consequences if they contact the police. Recently, concerns about immigration and victimization have been targeted at refugees who are at risk of being harmed by human traffickers, who warehouse them, threaten them, and physically abuse them with impunity [11, p. 1). Along the United States-Mexico border, thousands of immigrants from Central and South America are kidnapped, extorted, and physically abused by Mexican gangs who benefit from their exploitation [11, p. 18). Fussell found, for example, that the threat of deportation may result in illegal immigrant workers in the United States refraining from reporting their victimization and abuse in the workplace, and that such victimization is therefore not justified in official crime statistics [11, p. 6]."

The sentencing of Afro-Americans and Latino's in the United States is disproportionate. While the disproportionate sentencing of African-Americans has been documented for many years, Mauer and King [27] note that there has been recently a disproportionate increase in the number of Hispanic persons sentenced in state and federal prisons [27, pp. 4-7]. They found that, in 2005, Hispanics comprised $20 \%$ of the U.S. prison population, an increase of 45\% since 1990.

Table 2. Racial and Ethnic Rates of Incarceration in the US [27, p. 4).

\begin{tabular}{ll}
\hline Racial/ Ethnic group & Rate per $\mathbf{1 0 0 . 0 0 0}$ \\
\hline White & 412 \\
Black & 2.290 \\
Hispanic & 742 \\
\hline
\end{tabular}

Blaming immigrants, refugees and possible also expats for increasing crime rates in the United States of America, is the result of either racial bias or social disorganisation [11]. The Social Disorganisation theory was developed by the Chicago school and is in essence a theory that links crime to unfavourable neighbourhood conditions, like lower social class residents, unemployment, school dropouts, poverty, racial conflicts, unhealthy eating habits, addition to alcohol and drugs, absence of proper culturally differentiated healthcare etc. [28, pp. 122-123] According to the 'Social Disorganisation theory' residents in these neighbourhoods might come into contact with illegal activities, solicited and unsolicited. The social disorganisation theory might be the result of scientific racial bias. Racial bias that is often measured using the Implicit Association Test is a type of implicit bias that refers to the attitudes or stereotypes that 
result from individual or collective misunderstanding, actions and decisions that occur unconsciously [29]. This bias, which encompass unfavourable assessments, are often activated involuntarily and without the awareness or intentional control of the individual or collective. This bias is deep in the subconscious mind and differs from known prejudices of individuals or collectivists who, through this bias, can choose to hide in the guise of social and / or political correctness. Police officers for instance, come from all walks of life and they too have implicit bias, regardless of their ethnicity. Racial bias in criminal news is another manifestation of this bias. Illegal immigration which is classified as a criminal offence can be seen as a racial preference, taking into consideration the long legal bureaucratic procedures to get asylum.

A very striking quote about racial bias and microaggression is:

"To be black in the United States today means to be socially minimized. For each day blacks are victims of white 'offensive mechanisms' which are designed to reduce, dilute, atomize, and encase the hapless into his 'place.' The incessant lesson the black must hear is that she/he is insignificant and irrelevant [30, p. 3]"

Barnet differentiates between gateway and traditional cities. Gateway cities are cities with a relative large number of newcomers [11, p. 7]. Crime in immigrant neighbourhoods in gateway cities is not increasing or decreasing because newcomers are less willing to report a crime to the police. Vélez and Lyons said according to Barnet that social support infusion protects immigrants in gateway cities against crimes $[11$, p. 7 , see [31]].

Barnet finally concludes that "researchers in the United States have pointed out that the urban crime problem is not generated by immigrants, legal or undocumented, and that immigrants do not raise crime rates. Socially disadvantaged neighbourhoods may, however, make immigrant groups more susceptible to crime victimization when social support networks do not exist or are lacking. Despite the research findings on crime and immigration, the U.S. public mistakenly believes foreign-born immigrants to be dangerous criminals. To respond to undocumented immigration and the public fear of crime, anti-immigration laws enacted in the early 21 st century attempt to hasten the deportation processes for undocumented immigrants. Such laws have increased the workload in the U.S. courts and consequently deportation is likely when the undocumented immigrant has committed a serious violent crime or agrees to removal. Immigration laws and policies should take into account the unintended consequences of crime victimization on undocumented immigrants and global conditions that cause mass immigrations of people across dangerous borders" [11, p. 19]. What does this conclusion of Barnett means for the relationship between superdiversity and crime? The hypothesis is that this relation is negative, in other words, The hypothesis is that this relationship is negative, in other words, the more diverse the population is in terms of composition, the less crime. That might in particular be true for gateway cities. After all, immigration is a buffer against crime for at least the first generation newcomers $[11, p .8]$.

\section{Immigration and Crime in Europe}

Is Barnet's [11] conclusion applicable to Europe, is the next question that has to be answered. In the United Kingdom with the largest number of immigrants (Europeans, Africans and Asians) a drop was noticed in crime rates (official registered crime) compared to the areas with the second largest number of immigrants [25]. Secondly, there are relatively low crime rates in areas with a large proportion of immigrants [25, pp. 14-15). Nunziata shows that an increase of immigrants since 2000 in European countries ${ }^{14}$ has not led to more crime victimization. However, it leads to more fear of crime, which is consistent on the relation between immigration and crime in the United States of America. The results of Nunziata are consistent with the results found in the United States of America, namely a positive correlation between negative attitudes about immigrants and fear of crime [12, pp. 24-25].

Economic cost-benefit theory is according to Nunziata debatable. Economic cost-benefit theory is not favourable for immigrants since this theory (racial biased?) claims that immigrants and refugees may enter in illegal activities (read more crime) because opportunities for the first up to the fourth generation to go to school, get a job and lead a peacefully life in a neighbourhood are limited [12, p. 2]. This economic cost-benefit theory suggests that immigrants and refugees estimate their opportunities to participate in society higher and costs to commit crime lower than indigenous people when they might consider engaging in crime. Furthermore, this economic cost-benefit theory holds immigrants and refugees responsible for the drop in wages and an increase of illegal employment opportunities committing illegal activities. These accusations of costbenefit economists are deepened by placing the following comment: "Immigrants are younger than the indigenous population with the consequences that they may enter in more criminal activities than the indigenous people $[12, \mathrm{p}$. 4]." Nunziata uses on behalf of economists (not cost-benefit oriented) a counterargument, namely that immigrants and refugees when engaging crime, might not be able to find good legal defence and must face severe consequences like deportation to their motherland when convicted. One of the conclusions arising from the investigation of Nunziata is that economic cost-benefit theories are not able to predict whether immigrants and refugees commit more crime, and whether they are more often victimized by crime and/ or being a bystander of crime then indigenous people.

The final conclusion of Nunziata is: "Our empirical findings call for a better public assessment of the immigration phenomenon in western Europe, in particular

14 "The baseline sample consists of individuals residing in the period 2002-2008 in 16 western European countries, i.e. Austria, Belgium, Switzerland, Germany, Denmark, Spain, Finland, France, Greece, Ireland, Luxembourg, Netherlands, Norway, Portugal, Sweden and the UK, and 127 regions [32, p 47]." 
with regard to the implications for crime and for a more transparent approach to the discussion about the costs and benefits of immigration in host countries" [12, p. 28]. When studying crime and immigration it is also important to take prison population into consideration. The average proportion of foreign nationals' prisoners in Western European prison systems is currently 26 percent [32]. According to Eurostat 22.3 million people (4.4\%) of the 512.4 million people living in the EU on 1 January 2018 were non-EU citizens ${ }^{15}$. Apparently there is an overrepresentation (5.9 times more) of immigrants in European prisons.

\section{Victimized Immigrant Students and Hate Crimes}

First of all, in this section attention is paid to international students who might be labelled as Australian expats, and secondly hate crime in the EU in order to study the relation between crime on the one hand and immigrants and expats on the other. International students are rarely considered when it comes to insecurity [33]. In 2016 the number of international students worldwide add up to $4,9^{16}$ million. International Indian students in Melbourne (capital of the state Victoria in Australia) are overrepresented as victims of crime (among which violence and hate-crime) [33]. An explanation is that these international students lack support of their extended families. Australia had in 2017, 554,179 international students. "At the 2011 census, nearly 35 percent of Melbourne's population was born outside Australia, 45 percent reported both parents were born overseas and nearly one-third of the population spoke a language other than English at home" [33, p. 613). The International students and Indian students live in social disorganised neighbourhoods, mostly western ones in Melbourne with the cheapest thinkable housing in Australia. The conclusion of this study is: "For our participants, the neighbourhood contexts where international students resided rendered them vulnerable to racially motivated and/or opportunistic street crimes committed by delinquent young males from a variety of backgrounds. Although the relationship between racial crimes and crimes of opportunity was difficult to unpack, we argue that the attacks against students were targeted and non-random. Being an Indian student in a disadvantaged community context signalled vulnerability, which in turn led to victimisation. On some occasions, this vulnerability stemmed from the student's lack of family support and low levels of informal social control in the neighbourhood. For others, their ethnicity provided the motivation for other young men in the neighbourhood to attack them [33, p. 623]."

\subsection{Hate Crimes}

In 14 European countries hate crimes were studied against mainly immigrants via two surveys 2004-2005 and 2010 [26]. The risk to become a victim of hate crime is caused by a young age, by being an immigrant and to lesser extent by (large) cities [26, p. 13]. The question in the International Crime Victims Survey of hate-crime is [26, p. 4]: "In the past 5 years, did you, or any member of your immediate family fall victim of a crime because, or partly because of your nationality, race or colour, religious belief or sexual orientation?" The operationalization of the question of being an immigrant is operationalized as follows [26]: "Do you consider yourself or anyone in your family an immigrant in [country of residence]?"

The results are [26, p. 10]: "On average, $2.8 \%$ of the West European population said they were victim of a hate crime in the course of 2004. Among the 15 'old' member states of the $\mathrm{EU}$, there is considerable variation in the extent of hate crime. The highest percentages are found in France, Denmark, Luxembourg, Belgium, the United Kingdom, and the Netherlands (above 4\%). Rates of hate crime below $2 \%$ are found in Finland, Italy, Portugal, Greece, and Austria [34]. On average $10 \%$ of the immigrant population have been victims of hate crime in 2004 , compared to $2 \%$ of nonimmigrants."

These hate-crime results collected in a classical victimological tradition (opportunity theory) corresponds to EU research that shows that the Netherlands discriminates an excludes Muslims. The Netherlands is in the top two in the EU after Greece [35].

\subsection{Theoretical Explanations for Hate-crimes}

Van Kesteren [26] suggests that hate-crime might be explained by the opportunity theory [36]. Van Kesteren is not explicit about how to operationalize the opportunity predictive factors of hate-crime, namely attractiveness, proximity and exposure. Exposure might be the number of contact between immigrants, refugees and indigenous people in a defined region or city and proximity for instance the number of immigrants and refugees (but also expats) in one's own neighbourhood, community, apartments complex or street. Attractiveness is not easy to operationalize when it comes to hate-crimes. A possible operationalization (to be jealous) is the number of immigrants and refugees in neighbourhoods who are favoured or not when receiving a house, job and other benefits such as unemployment benefits [37]. Other theoretical frames suggested by Van Kesteren $[26$, p. 8$]$ are the so called scapegoat theory, economic threat or resource competition hypothesis and sheer hatred or otherness. The last one, sheer hatred of otherness, has also been labelled as cultural 'THEY-US' characteristics. In the United Kingdom the economic threat theory has been elaborated by Wessendorf in her study about equal versus unequal distribution of houses for immigrants, refugees and indigenous people with a high priority on the housing list [37].

Another hypothesis for the existence of hate-crime can be deducted from the results of the Implicit Association Test. The results of a meta-analysis of the Implicit Association 
Test for intergroup discrimination are: "both studies agreed that, when considering only findings for which there is theoretical reason to expect positive correlations, predictive validity of Black-White race IATs is approximately $r=.20$. Second, even using the two meta-analyses' published aggregate estimated effect sizes, the two agreed in expecting that more than $4 \%$ of variance in discrimination-relevant criterion measures is predicted by Black-White race IAT measures. The correlational predictive validity of IAT measures represents ... a discriminatory impact with very substantial societal significance [38]." This meta-analysis might be considered as support for the pure hatred hypothesis against immigrants and refugees.

In other words, immigrants are paying a high price for immigrating to western countries, the countries where they hope to get a second chance, especially in social disorganized neighbourhoods, like the dominant white neighbourhoods in Melbourne. The data in this paragraph suggest that for victimization the relation between superdiversity and crime (victimization) is positive.

\section{Neighbourhoods, Immigration and Crime Rates}

This section examines the relation between newcomers and crime in neighbourhoods. Wessendorf points out how recent immigrants (newcomers) settle in superdiverse neighbourhoods [39]. She introduces 'new glasses' to observe immigration in the 'New World' where immigration has been going on for much longer. Her in-depth interviews are based on newcomers who settle down in Birmingham ( $46,9 \%$ of the $1,073,045$ people is of foreign origin) and East London (Borough of Hackney with $63,8 \%$ of 257,379 inhabitants of foreign origin), both superdiverse, however East-London more than Birmingham. In this article, the assumption is undermined that the settling process of newcomers in a new fatherland, is mainly determined by the motherland descent and ethnicity of the newcomer. In order to demonstrate the foregoing, Wessendorf uses a subdivision of immigration in three phases: initial, group and mass immigration. Immigration of newcomers starts according to Wessendorf as an initial pioneer phase, and might lead to group and mass immigration via information and feedback loops about their new fatherland. She considers immigration as a system where people, goods, information, and services continuously move back and forth from fatherland (s) to motherland (s) countries and/or continents [39, pp. 6-7]. Up to date information about their new fatherland can be seen as 'gasoline' for family members, friends, villagers and city dwellers of the former newcomers. This mechanism is called the immigration chain. This immigration chain provides newcomers in the new fatherland with information about where they can live, receive education, work and how transportation is arranged.

Her comparative study shows that newcomers have to deal with five mechanisms. "These mechanisms are: a) deskilling and employment (new work experiences seldom matches the old work and education experiences). Work is found via the immigration chain, either via another former immigrant or someone of the same or other ethnic group,

b) legal status (being undocumented or an asylum seeker often means a ban on working legally, with the result, that opportunities to build networks are declining),

c) social networks and friends (newcomers rely on foundation networks for work, education, housing and leisure. Speaking the same language might be important),

d) sense of belonging in the neighbourhood (if a neighbourhood is 'too white', the sense of belonginess will be lacking. Humans wish to see and meet in their own neighbourhood 'Our Kind of People'),

e) multicultural adaptation (in particular East and South Europeans have to get used to the big differences between their relatively cultural homogenous motherland and their superdiverse fatherland)."

These five mechanisms show that neither London nor Birmingham deal with the available social capital of newcomers. Not dealing might be called intended or unintended exclusion. Balancing on a cord has consequences for the behaviour of newcomers, in particular risk-taking behaviour, such as committing crime. Newcomers therefore tend to be careful. A proof can be found in Light [40, p. 6]. "Many immigrants are driven by the pursuit of economic and educational opportunities for themselves and their families, and clandestine immigration requires a substantial amount of motivation and planning. As such, undocumented immigrants may be selected on attributes that predispose them to low criminal propensity, such as high motivation to work and ambition to achieve. Related to this point, unauthorized immigrants, much more so than lawful immigrants, have strong incentives to avoid criminal involvement for fear of detection and deportation. In both scenarios, increases in undocumented immigration should decrease violent crime over time."

The key question that still needs to be answered is, what is the relationship between immigration (old and newcomers) and crime on the neighbourhood level? Crime is defined as all kinds of experiences with crime, such as being a victim, being a witness and committing a crime. It was stated earlier in this chapter that the relationship between being a refugee and committing crime is negative. This result has been confirmed by a longitudinal study in the United States of America from 1990 to 2014 in about fifty states about the relation between undocumented immigration and violent crime [40]. This conclusion is based on victimization data, showing that this result may be caused by underreporting or selective immigration to avoid crime."

A serious accusation though of general exclusion of undocumented immigrants in the United States of America is: "between 2005 and 2010, state legislatures enacted more than 300 anti-immigration laws, including regulations that deny public benefits, services, and health care to 
unauthorized immigrants, as well as laws that punish employers who hire undocumented workers and landlords who rent to unauthorized immigrants. For undocumented immigrants, these laws exacerbate the fact that they are denied almost all forms of federal aid and by definition have no political representation. According to Menjívar and Abrego, the cumulatively injurious effects of immigration laws on the daily lives of unauthorized immigrants represent a form of "legal violence" or what Kubrin, Zatz, and Ramirez called "state-created vulnerabilities." Regardless of the term, the lack of legal standing may have several important implications for criminal behaviour [40, p. 4)." Another confirmation of the afore mentioned results including newand oldcomers and property crime is the statement: "Metropolises with higher percentages of foreign-born populations had consistently lower rates of murder, robbery, burglary, and larceny [41, p. 71]."

Hardly any reliable data is available about the relationship between crime and immigration at the neighbourhood level. Crime at the neighbourhood level is often defined as police data that are no more than a selective fraction of 'reality'. An example of outcomes between crime (= police data) and immigration can be found in the following Belgium article [42]: "Our analysis of crime rates in Belgium, however, did not reveal any meaningful significant relationship between the presence or the inflow of ethnic minorities and the rates of registered property and violent crime. Unemployment rates clearly are the most important determinant of property and violent crime. For the two largest ethnic minority groups in Belgium (Turkish and Moroccan communities), we did not observe any significant relationship with crime rates." Another source is the following one: "Sampson and Raudenbush, see Bernat, [11, p. 6] reviewed the concept of "broken windows" in order to ascertain if a community's view (perception) of social disorder is shaped by racial bias. Utilizing four data sets for Chicago's neighbourhood blocks in the 1990s, Sampson and Raudenbush found that community residents' and leaders' views of their neighbourhood were influenced by the community's racial composition. They suggest that negative perceptions of neighbourhoods are shaped by racial bias rather than by observations of disorder. In this regard, Latinos (a large number of whom were Mexican immigrants) in Chicago perceived their neighbourhoods to have significantly more social disorder when the neighbourhood was at least a $25 \%$ African American.”

\section{Micro Dutch Studies About the Victim, Bystander and Offender Cycle}

Researchers from Europe and United States of America who investigated the relationship between immigration and crime focussed on the question: "Is there a relationship between committing crime and immigration?" Fact finding is necessary because political leaders like Donald Trump, Viktor Orbán, Giuseppe Conte, Matteo Salvini, Björn Höcke,
Udo Landbauer, Geert Wilders and Thierry Baudet supported by populist media have a political program that tells us that newcomers and oldcomers increase and will increase national and local crime rates. Because of this dominant immigrant and refugee hostile statements, concrete victim experiences of immigrants and refugees are not fully reflected. Apart from the above, the emphasis has shifted to crime trends and the number of people (read immigrants and refugees) in prisons. This section therefore focusses on micro studies in the Netherlands into experiences with victimization that took place in starting and advanced super-diverse cities and the consequences thereof. Such studies are undoubtedly also available in other European countries and the United States of America; however I do not have them.

Provocative is the title of Frank Bovenkerk's book 'Moroccan in Europe and criminal in the Netherlands' in which the relationship between immigration and crime is investigated [7]." Bovenkerk's data show that "the Netherlands is under the spell of a unique and persistent social problem of crime among boys of the second (and third) generation of immigrants with a Moroccan background. These boys cause nuisance in the neighbourhood, commit robberies and are prominent in the world of drug trafficking." These facts are astonishing since Moroccan immigration (mainly oldcomers) in the Netherlands is at least 50 years old. Quite a number of the Moroccan immigrants (mainly Berbers) in Europe are rooted in the Rif (north part of the Moroccan Kingdom). "The Rif ${ }^{17}$ has some fertile plains and stretches from Cape Spartel and Tangier in the west to Berkane and the Melwiyya River in the east and from the Mediterranean in the north to the Ouergha River in the south. It is separated into Eastern Rif (Al Hoceima, Driouch, Nador, Berkane) and Western Rif (Tanger, Tetouan, Achaouen, Taounate)." Bovenkerk compares crime trends of the Netherlands (Amsterdam, Rotterdam, The Hague and other large cities) with Germany (Dusseldorph and Frankfurt), Belgium (Flanders), France (partly absence of registering ethnic origin) and also Spain and Italy who have to do with recent immigration of Moroccans in order to find traces of crime committed by Moroccan boys [7].

Bovenkerk found in a selection of northern and southern European countries that Moroccan boys were involved in drugs trade. These boys were also a role model for part of the second generation Moroccan boys. The traces of criminality in the Netherlands of Moroccan boys rose far above the other European countries that were studied. Bovenkerk (2014) said that in between half and two third of the Moroccan boys less than 23 years in the Netherlands can be found in the police recognition service system (in Dutch: politie herkenningsdienst systeem) as a suspect of at least one serious criminal crime. The cause for the impact on crime rates in European countries of Moroccan boys could be that caregivers feel that they lost control of their sons [7].

Again, Moroccan boys had a considerable impact on the nature and number of criminal incidents in the Netherlands in

17 https://en.wikipedia.org/wiki/Rif 
contrast to other northern and southern European countries [7]. Why is a legitimate question? Bovenkerk raised several explanations. Some of them will be discussed. The first explanation is that these Moroccan sons lost respect for their fathers, especially when their fathers lost their jobs after the oil crisis (1973) and restructuring of the economy (early 1980s). Their fathers became unemployed after a life of heavy and hard work. Moreover, they spoke virtually no Dutch and were not familiar with the socio-economic structure in the Netherlands. The second explanation is that the Dutch healthcare and welfare institutions pasted the label 'child abusers' on these fathers. This label deteriorated their position as patriarch of the family. Youth care invaded regularly their homes and accused these fathers of child abuse. A pedagogical blow was common. But the Dutch health and welfare institutions did not know that at the time

Although the explanation for the significant impact of Moroccan boys on crime in the Netherlands is both socioeconomic and pedagogical, in my opinion that impact can also be described as the mass victimization of Moroccan fathers and their sons indirectly. The Dutch official response to these Moroccan fathers can possibly be seen as incompetent and ignorant and not as pure racial hatred. "The Netherlands at the time was a country with libertine views and seemingly unlimited personal freedom [7]."

Scheffer claims the following relationship between immigration and crime in the Netherlands [3, p. 34]: "crime did not come to the Netherlands with immigration, but is the product of confusion caused by the clash of very different forms of law enforcement. Young people from immigrant families who are raised fairly authoritatively are used to laughing at police officers who prefer to negotiate rather than arrest. In addition, Scheffer mentions [3, p. 33]: "Many Moroccan youth feel victimized. A victim feels abused, misunderstood and not safe. They have to get rid of that victim role to find an identity. These words summarize what is often associated with immigrants. Some are worried about the resentment and aversion they feel in their own community towards society. Many of these 'victims' have a fast career as perpetrators, which is also deceptive for immigrant communities in the Netherlands. The fear of Moroccan youth in Amsterdam is now proverbial." Scheffer's arguments and those of Bovenkerk about the impact of Moroccan boys on crime might be the result of a clash between cultures (the majority of the Moroccans are living in the Randstad).

Lahlah tried to provide an answer in her dissertation $(\mathrm{PhD})$ about the question [8]: "is the overrepresentation of juvenile delinquency of Moroccan boys (second and third generation) associated with victimization at home?" This question fits perfectly with the subject being studied in her research, namely transitions between becoming a victim, bystander and perpetrator. Lahlah studied almost 500 Moroccan or DutchMoroccan boys (in between 15 and 18 years) from five high schools and two youth probation services, located in three major cities and two rural districts and compared them with Dutch boys. The results speak for themselves. According to
Lahlah, $60,7 \%$ of the Moroccan boys did experience parental physical violence. This figure was for Dutch boys of almost the same age, $6 \%$. Furthermore, $17 \%$ of the Moroccan boys experienced sexual abuse by a family member. This is for Dutch boys $4,9 \%$. On top of this all, $45,5 \%$ of MoroccanDutch boys experienced physical violence between parents. This number is for Dutch boys $17,8 \%$. These outcomes can be seen as a confirmation of transitions in the cycle of becoming victimization, bystander and perpetrator. These results are a disgrace for the victim surveys. Dutch victim surveys clearly don't detect these trends which is surprising since the number of Moroccan-(Dutch) becoming a victim of violence (in society, at school, and extended family) is large.

Two other sources, based on a dissertation $(\mathrm{PhD})$, are added in order to reveal the relationships between becoming a victim, bystander and offender. The first one is that of Ftitache [43] and the second one that of Van der Ven [9]. One of the first longitudinal study of primary school pupils had as an striking outcome [43]: "immigrant Dutch children arrive at primary school compared to original Dutch pupils with more externalizing problem behaviour (this is a label been used by Dutch teachers and pupils). Their behaviour is labelled as aggressive, oppositional-rebellious and less prosocial behaviour. Moreover, immigrant Dutch children are more often bullied by their peers." This behaviour was not noticed by teachers and fellow-pupils during the whole school carrier of these immigrant children. Fellow-pupils isolated these children in the class. They are, as it were, not part of primary school, are not appreciated and are rejected by their peers. Primary school teachers did not intervene, with the result that this externalizing problematic behaviour of immigrant children is still present when these children leave primary education at the age of twelve (this transition at 12 years old from primary education to high school exists only in the Netherlands)." Ftitache, also labels these results as the consequences of mislabelling. Westerns label 'normal' behaviour of immigrants as 'abnormal' since they are not used to experience this behaviour and according to their cultural standards this behaviour is 'abnormal'. Ftitache's data can be seen as a confirmation of the cycle of becoming a victim, bystander and perpetrator, but also adds a cultural component that has not yet been revealed, namely the cultural labelling of the other's behaviour in a colour-blind manner as if all behaviour can only be assessed according to the Dutch standard.

The second source is that of Van der Ven [9] who found that immigrants (first and second generation) with a dark skin are running a five time higher risk of psychotic disorders than original Dutch people and immigrants with a white skin twice as higher risk. Psychotic symptoms are for instance delusions and hallucinations. This is the case for $7 \%$ of the Dutch population and disappears in $75 \%$ of those who experience these psychotic symptoms (based on research of Jim van Os see, [9, p. 169]. Furthermore immigrant males run a twice as high risk of psychotic hallucinations and delusions than immigrant females. For immigrant children the hallucinations and delusions are caused by bullying and 
for adult immigrants by polarization, discrimination and racism (excluding the other) [9].

It is striking that these five Dutch scientists mainly write about Moroccans. The data in this chapter is a demonstration of the so called victim, bystander and offender cycle [4]. This research by these Dutch scientists is explicit about the relation between victimization and crime. Becoming a bystander remains out of the picture. This is the missing part in research. But the aforementioned researchers revealed several psychological mechanisms that might explain how victimization might turn youngsters in perpetrators. The first mechanism is continuously experiencing discrimination, exclusion and polarization in Dutch society. The second mechanism is psychotic attacks as a result of the first mechanism. The third psychological mechanism that ruins the basic scheme of trust and safety between humans, is family violence and sexual abuse. This psychological mechanism also violates collectivist principles, such as respect for elderly and the group that has in collectivism a higher priority than an individual. The fourth mechanism is pedagogical, and states that caregivers of immigrant children are abusers instead of saying they give a corrective tap.

\section{Conclusions}

The goal of this article was unravelling relations between immigration and crime at the level of a continent, state, (superdiverse) city and neighbourhood. This article focusses on the United States of America, Europe (with a special paragraph about the Netherlands), Australia and New Zealand, western countries and continents. Direct relations are not yet measured in research. Since I am a psychological victimologist I will use victimology as a reference for the main outcomes.

Victimology has three goals. The first goal is research into victimization, its consequences and possible solutions. The second goal is victim advocacy, like improving victims' rights. Unfortunately, the main scope in this article is the retributive western criminal justice system. The third and last goal is improving psychosocial and psychic healthcare, like for instance victim schema's [44]. The aforementioned reasoning in this article falls within the scope of research and victim advocacy.

Populist political leaders and media are blaming immigrants (old and newcomers) for an increase in committing crime. The unfortunate facts are that old and newcomers are overrepresented in the prison system in the United States of America and Europe. Factfinding in the United States of America and Europe shows a slight trend that more immigrants (new- and oldcomers) may result in less crime. An unexpected by-product of the aforementioned populist opinions is an increase of fear of crime. Correcting incorrect images about offences and perpetrators is a possible intervention for repairing the distortion of these relations between crime and immigration [45].

The main conclusions of unravelling the relations between crime and immigration are:

1. The relation between immigration and crime trends has a covariate namely superdiversity.

2. Ignoring immigrants in research and policy should be out of the question since they together outnumber in superdiverse cities in western countries and continents the indigenous people.

3. The relation between immigration and committing crime is negative.

4. The more immigrants (old- and newcomers) the higher the fear of crime rates.

5. The relation between immigration and victimization is positive in particular at the superdiverse neighbourhood level if those neighbourhoods are dominant white, socially disorganised, and if support for newcomers is more or less absent because of no connection with a founding-networks, extended families or the lack of state-organized support.

I like to raise the following statement: old- and newcomers are not protected by governments. They feel that notifying a crime to the police might lead to ethnic profiling or simply forcing them to return to the unsafe motherland. Immigrants (old- and newcomers) are furthermore victimized because they are discriminated, polarized or excluded in many societal systems like neighbourhoods, education, workforce, health systems and on top of that by their own extended families. These forms of victimization worsens if immigrants (old- and newcomers) are Muslims. In other words, immigrants are victimized by human trade, illegal work and the most heavy and dirty work that exists in western society. These victims come into contact with a society that does not protect them against mass victimization. Some of them are pushed over the edge and may commit crimes themselves. You can speculate about their motives. Possible motives are revenge and wrong role models.

This immense number of victim experiences of immigrants, refugees and expats (children and adult) are not yet included in victim surveys. We might speculate about the reasons. Most probably do these surveys suffer from cultural bias with regard to sampling and survey questions.

This chapter also pays attention to the relation between immigration and crime at the superdiverse level of neighbourhoods in western cities. Attention is paid to a major change in immigration patrons. The $20^{\text {th }}$ century immigration consisted of large group of immigrants coming to new western fatherlands and superdiverse cities, hoping that they might have a more prosperous live, better education for their children, work etc. The 21 th century immigration however consists of large numbers of small groups of newcomers coming from several continents like South-America, Africa, South-east and East-Asia and in Europe mainly East-Europe and states in these continents. Key-mechanisms of the latter immigration in the 21 th century is the immigration chain with information, feedback loops and founding-networks in the new fatherland (Our Kind of People who provide information about resources and support). I only found Belgium and Australian research showing that superdiverse 
neighbourhoods who are either socially disorganized and too white criminalize immigrants (old- and newcomers and international students, [33].

In the old and new super-diverse cities, also along the New Chinese Silk Roads, more attention should be paid to negative labelling of immigrants, refugees and expats. Negative labelling has also an impact on fear of crime among the public. This should be done on the basis of wellmonitored research that also takes into account the growth towards super-superdiverse cities.

\section{References}

[1] Frankopan, Peter (2016). The Silk roads. A new history of the world. Alfred A. Knopf.

[2] Frankopan, Peter (2018). The new silk roads. The present and future of the world. Bloomsbury.

[3] Scheffer, Paul (2010). Het land van aankomst. De Bezige Bij.

[4] Steinmetz, Carl H. D. (1985). Bystanders of crime: Some results from a national survey. Victimology; an international journal. Volume 10, 1985. Number 1-4. Pp. 441-460. @ Victimology. Printed in the USA. 0361-5170/85/ $\$ 1+0.10$.

[5] Steinmetz, Carl H. D. (2018). Voorkom discriminatie, uitsluiting en polarisatie. Sociaal bestek. Tijdschrift voor werk, inkomen en zorg. DOI: 10.1007/s41196-018-0101-z

[6] Ramose, Mogobe (2017). Ubuntu. Stroom van het bestaan als levensfilosofie. Ten Have.

[7] Bovenkerk, Frank (2014). Marokkaan in Europa, crimineel in Nederland. Boom Lemma uitgevers.

[8] Lahlah, A. (2013). Invisible Victims? Ethnic differences in the risk of juvenile (violent) offending of Dutch and MoroccanDutch adolescent boys. Doctoral dissertation. Ridderkerk: Ridderprint.

[9] Van der Ven, Elisabeth Maria Anna (2016). Ethnic minority position as risk indicator for autism-spectrum and psychotic disorders. Doctoral Academisch proefschrift. Universiteit van Maastricht.

[10] Crul, Maurice, Schneider, Jens, \& Lelie, Frans (2013). Super Diversiteit. VU University Press.

[11] Bernat, Francis (2019). Immigration and crime. Oxford Research Encyclopaedia of Criminology. DOI: 10.1093/acrefore/9780190264079.013.93.

[12] Nunziata, Luca (2014). Immigration and Crime: New Empirical Evidence from European Victimization Data. IZA DP No. 8632. Discussion Paper No. 8632 November 2014: http://ftp.iza.org/dp8632.pdf.

[13] Leerkes, Arjen, Martinez, Ramiro \& Groenevel, Pim (2018). MINORITY PARADOXES: ETHNIC DIFFERENCES IN SELFREPORTED OFFENDING AND OFFICIAL CRIME STATISTICS. British Journal of Criminology. DOI: 10.1093/bjc/azy021

[14] Landgrave, Michelangelo \& Nowrasteh (2019). Incarcerated Immigrants in 2016. Their Numbers, Demographics, and Countries of Origin. Immigration. Research and policy brief.
Cato Institute.

[15] Unnever, James D. (2018). Ethnicity and Crime in the Netherlands. International Criminal Justice Review, 1-18. DOI: $10.1177 / 1057567717752218$.

[16] Bell, Brian (2014): Crime and immigration, IZA World of Labor, ISSN 2054-9571, Institute for the Study of Labour (IZA), Bonn, Iss. 33, http://dx.doi.org/10.15185/izawol.33 Bernat, Frances (2019). Immigration and Crime. Oxford Research Encyclopaedia of Criminology. Online Publication Date: Apr $2017 \quad$ DOI: 10.1093/acrefore/9780190264079.013.93.

[17] CBS (2018). Jaarrapport Integratie 2018. Centraal Bureau voor de Statistiek. Henri Faasdreef 312, 2492 JP Den Haag. Retrieved from www.cbs.nl.

[18] Vertovic, Steven (2019). Talking around superdiversity. Ethnic and Racial Studies 2019, vol. 42, NO. 1, 125-139. https://doi.org/10.1080/01419870.2017.1406128

[19] Foner, Nancy, Duyvendak, Jan Willem, and Kasinitz, Philip (2019). Introduction: superdiversity in everyday life. Ethnic and Racial Studies. 2019, VOL. 42, NO. 1, 1-16. https://doi.org/10.1080/01419870.2017.1406969

[20] Eurostat (2019). Statistics explained. https://ec.europa.eu/eurostat/statisticsexplained/

[21] Grillo, Ralph (2015). Reflections on Superdiversity by an Urban Anthropologist, or "Superdiversity So What? ResearchGate. https://www.researchgate.net/publication/275155983_Reflectio ns on Superdiversity by an Urban Anthropologist or Super diversity_So_What.

[22] Vertovic, Steven, Hiebert, Daniel, Gamlen, Alan and Spoonley, Paul (2019). Max Planck Institute. For the Study of Ethnic and Religious Diversity. https://www.mmg.mpg.de/254627/2018superdiversity.

[23] Tutu, Desmond, M., Tutu, Mpho, A. (20140. The book of Forgiving. The fourfold path for healing ourselves and our world. HarperCollinsPublishers.

[24] Peguero, Anthony, A., Popp, Ann, Marie \& Koo, Dizie, J. (2015). Race, Ethnicity and School based Adolescent Victimization. Crime \& Delinquency 2015, Vol. 61 (3) 323349. DOI: $10.1177 / 0011128711398021$.

[25] Ignatans, Dainis and Roebuck, Tim (2018). Do more immigrants equal more crime? Drawing a bridge between first generation immigrant concentration and recorded crime rates. Applied Criminology and Policing Centre, University of Huddersfield. DOI: 10.5920/css.2018.03

[26] Van Kesteren, John (2016). Assessing the risk and prevalence of hate crime victimization in Western Europe. International Review of Victimology. DOI: 10.1177/0269758015627046.

[27] Mauer, Marc, and King, Ryan S. (2007). Uneven Justice: State Rates of Incarceration By Race and Ethnicity. The Sentencing Project. www.sentencingproject.org.

[28] Kubrin, Charis E. and Wo, James C. (2016). Social Disorganization Theory's Greatest Challenge: Linking Structural Characteristics to Crime in Socially Disorganized Communities. In Alex R. Piquero (Eds.) The Handbook of Criminological Theory, First Edition. Edited by. (C) 2016 John Wiley \& Sons, Inc. Published 2016 by John Wiley \& Sons, Inc. 
[29] Richeson, Jennifer, A. and Nussbaum, Richard, J. (2003). The Impact of Multiculturalism versus Colour-blindness on Racial Bias. Journal of Experimental Social Psychology 40 (2004) 417-423. doi: 10.1016/j.jesp.2003.09.002.

[30] Huber, Lindsay, Pérez and Solorzano, Daniel G. (2014). Racial microaggressions as a tool for critical race research. Race Ethnicity and Education, http://dx.doi.org/10.1080/13613324.2014.994173.

[31] Vélez, M. B., \& Lyons, C. J. (2012). Situating the immigration and neighbourhood crime relationship in multiple cities. In R. Martinez, M. S. Zatz, \& C. E. Kubrin (Eds.), Punishing immigrants: Policy, politics, and injustice (pp. 159-177). New York: New York University Press.

[32] Ugelvik, Thomas (2015). Global Prison Ethnography. Department of Criminology and Sociology of Law. University of Oslo. In The Palgrave Handbook of Prison Ethnography, DH Drake, R Earle and J Sloan (eds), Basingstoke: Palgrave.

[33] Forbes-Mewett, Helen, and Wickes, Rebecca (2012). The neighbourhood context of crime against international students. Journal of Sociology. 2018, Vol. 54 (4) 609-626. (C) The Author (s) 2017. Article reuse guidelines: sagepub.com/journals-permissions. DOI: 10.1177/1440783317739696 journals.sagepub.com/home/jos.

[34] Van Dijk, Jan, Van Kesteren, John, and Smit, Paul (2007). Criminal Victimisation in International Perspective. Key findings from the 2004-2005 ICVS and EU ICS. Boom Juridische uitgevers.

[35] EU (2017). Second European Union Minorities and Discrimination Survey. Muslims - Selected findings, (C) European Union Agency for Fundamental Rights, 2017.

[36] Steinmetz (1979). An (empirically tested) analysis of victimization risks. Research and Documentation Centre of the Ministry of Justice, The Hague, the Netherlands, National Criminal Justice Reference Service (NCJRS). Microfiche. United States Department of Justice Washington, D. C. 205\&1.

[37] Wessendorf, Suzanne. (2014) 'Researching social relations in super-diverse neighbourhoods: Mapping the field', IRiS Working Paper Series, No. 2/2014. Birmingham: Institute for Research into Superdiversity. www.birmingham.ac.uk/iris.

[38] Greenwald, A. G., Banaji, M. R., \& Nosek, B. A. (2015). Statistically small effects of the Implicit Association Test can have societally large effects. Journal of Personality and Social $\begin{array}{llll}\text { Psychology, } & 108 & \text { (4), } & \text { 553-561. }\end{array}$ http://dx.doi.org/10.1037/pspa0000016.

[39] Wessendorf, Suzanne. (2018). Pathways of Settlement among Recent Migrants in Super-diverse Areas. IRIS WORKING PAPER SERIES, NO. 25/2018. www.birmingham.ac.uk/iris.

[40] Light, MICHAEL, T. and Miller, Ty (2017). Does Undocumented Immigration increase Violent Crime? Criminology. 2017 May; 56 (2): 370-401. doi: 10.1111/17459125.12175.

[41] Adelman, Robert, Reid, Lesley, Williams, Markle, Gail, Weiss, Saskia \& Jaret, Charles (2017). Urban crime rates and the changing face of immigration: Evidence across four decades. Journal of Ethnicity in Criminal Justice, 15: 1, 52-77, DOI: 10.1080/15377938.2016.1261057.

[42] Bircan, Tuba, and Hooghe, Marc (2011). Immigration, diversity and crime: an analysis of Belgian national crime statistics, 2001-6. European Journal of Criminology 8 (3) 198-212. DOI: $10.1177 / 1477370811403443$.

[43] Ftitache, Bouchra (2015). Psychosocial and educational adjustment of Ethnic Minority School Children in the Netherlands. Doctoral Dissertation. Vrije Universiteit Amsterdam.

[44] Steinmetz, Carl H. D. (1990). Hulp aan slachtoffers van misdrijven. Effecten van slachtofferhulp en primaire opvang. Gouda Quint B. V.

[45] Winkel, Frans, Willem en Steinmetz, Carl H. D. (1985). Slachtofferschap en angst voor criminaliteit: een schokverwerkingsmodel. In Angst voor Criminaliteit. Theorie Onderzoek Interventie. Chapter: 2. Publisher: Amsterdam: Swets \& Zeitlinger. Editors: Frans Willem Winkel \& Adri van der Wurff. 